Protein and Peptide Letters, Vol. 9, No. 1, pp. 59-66, 2002

Bentham Science Publishers Ltd.

0929-8665/02\$35.00+.00

\title{
EXPRESSION AND PURIFICATION OF THE RECOMBINANT CONBR (CANAVALIA BRASILIENSIS LECTIN) PRODUCED IN ESCHERICHIA COLI CELLS
}

\author{
Nadia A. P. Nogueira ${ }^{1}$, Moema B. Grangeiro ${ }^{2}$, Rodrigo M. S. da Cunha ${ }^{2}$, Marcio V. Ramos ${ }^{3}$, Maria A. O. \\ Alves $^{2}$, Edson H. Teixeira ${ }^{4}$, Manoel Barral-Netto ${ }^{5}$, Juan J. Calvete ${ }^{6}$, Benildo S. Cavada ${ }^{4}$ and Thalles B. \\ Grangeiro ${ }^{2, *}$
}

${ }^{1}$ Depto. de Analises Clínicas e Toxicológicas, Universidade Federal do Ceará (UFC), Brasil; ${ }^{2}$ Laboratório de Citogenética e Genética Molecular, Depto. de Biologia, Centro de Ciências, UFC - 60.451-970, Fortaleza, Ceará, Brasil (thalles@ufc.br); ${ }^{3}$ Depto. de Biologia, UFC; ${ }^{4}$ BioMol-Lab, Depto. de Bioquímica e Biologia Molecular, UFC; ${ }^{5}$ Centro de Pesquisas Gonçalo Moniz, Fiocruz, Bahia, Brasil; ${ }^{6} \mathrm{CIB}$, CSIC, Madrid, Spain.

ConBr, a D-glucose/D-mannose-specific lectin from Canavalia brasiliensis seeds, was produced in Escherichia coli from a cDNA clone subcloned to pET15b expression vector. The recombinant lectin ( $\mathrm{rConBr}$ ) was purified by onestep immobilized metal-affinity chromatography using an amino-terminal hexahistidine tag. By SDS-PAGE and Western blot, $\mathrm{rConBr}$ was highly pure with an apparent molecular mass of $37 \mathrm{kDa}$. N-terminal sequence analysis revealed a single sequence, confirming the identity of the expressed protein as the pre-pro-ConBr.

\section{INTRODUCTION}

Lectins are a structurally heterogeneous group of carbohydrate-binding proteins of non-immune origin comprising distinct families of evolutionarily related proteins [1]. The most thoroughly investigated lectins are those from plants, in particular from the family Leguminosae. Legume lectins are a large group of structurally similar proteins with distinct carbohydrate specificities. Concanavalin A (ConA), from the seeds of Canavalia ensiformis (family Leguminosae, tribe Phaseoleae, subtribe Diocleinae), was the first lectin to be isolated [2], sequenced [3-4] and to have its three-dimensional structure determined by x-ray crystallography [5-6]. The many biochemical, biophysical, and structural studies carried out on ConA make this protein the best-characterized plant lectin so far as well as the prototype of legume lectins.

ConBr, a lectin from seeds of C. brasiliensis, was first isolated by Moreira \& Cavada [7]. Like ConA, ConBr displays the same primary carbohydrate binding specificity for residues of D-glucose, D-mannose and derivatives but both lectins possess enhanced affinities for the branched chain trimannoside, 3,6-di-O- $(\alpha-\mathrm{D}-$ 
mannopyranosyl)-D-mannose [8], which is found in the core region of all asparagine-linked (N-linked) carbohydrates. Furthermore, ConBr and ConA essentially recognize the same set of binding epitopes on the structure of the trimannoside [9]. However, it has been shown by hemagglutination inhibition and isothermal microcalorimetry (ITC) studies that these two lectins differ in their fine carbohydrate binding specificities, i.e. they have differential binding specificities for complex type carbohydrates [8-9]. Indeed, significant differences in the intensities of some biological activities elicited by ConBr and ConA (induction of rat paw edema, peritoneal macrophage spreading in mouse, and in vitro human lymphocyte stimulation) have been observed [10-13]. These differences are believed to be, at least in part, the result of their distinct fine carbohydrate binding specificities.

The X-ray crystal structure of ConBr is very similar to ConA [14] and the amino acid residues that in ConA are involved in the carbohydrate-binding site (Tyr12, Asn14, Leu99, Tyr100, Asp208 and Arg228) are completely conserved in the primary structure of ConBr. For instance, the x-ray crystal structure of ConBr shows only two amino acid changes relative to ConA [14-15]: Gly-58 and Gly-70 in ConBr are replaced by Asp and Ala, respectively, in ConA. Neither of these residues is near the carbohydrate binding sites in both lectins, and only small changes in the quaternary structures of the two proteins were observed. However, these two amino acid replacements result in significant changes of the thermodynamic binding parameters of $\mathrm{ConBr}$ and $\mathrm{ConA}$ to complex carbohydrates [8-9]. These results indicate that non-contact residues in these lectins, even those distant from the carbohydrate-binding sites, modulate their thermodynamic binding parameters [9].

Our long term goal is to investigate, by means of site-directed mutagenesis, the hypothesis that amino acid substitutions in very related lectins such as ConBr and ConA have long range effects on their thermodynamic binding parameters to carbohydrates. As a first step to achieve this aim, recombinant $\mathrm{ConBr}$ ( $\mathrm{rConBr}$ ) was produced in Escherichia coli from a cDNA clone encoding the pre-pro-lectin subcloned to pET15b expression vector and the rConBr purified by metal-affinity chromatography using an amino-terminal hexahistidine tag.

\section{MATERIAL AND METHODS}

Bacterial strain: Cells of $E$. coli strain BL21( $\lambda$ DE3) carrying the plasmid pET15b-conbr were obtained as described by Grangeiro [16] and stored as glycerol stocks at $-20{ }^{\circ} \mathrm{C}$.

Expression of recombinant ConBr (rConBr) in Escherichia coli: A single colony of E. coli BL21( $\lambda$ DE3) carrying pET15b-conbr was inoculated into $500 \mathrm{ml}$ of LB medium containing $100 \mu \mathrm{g} / \mathrm{ml}$ ampicillin. The cells were grown at $37{ }^{\circ} \mathrm{C}$ with vigorous shaking until the $\mathrm{A}_{600} \mathrm{~nm}$ reached $0.6-1.0$. Protein expression was induced by $1 \mathrm{mM}$ isopropyl- $\beta$-D-thiogalactoside (IPTG). The cells were grown for a further $5 \mathrm{~h}$ at $37{ }^{\circ} \mathrm{C}$ and centrifuged $(5,000 \mathrm{x}$, 10 min, 4 oC). The supernatant was discarded and the cell pellet was resuspended in TES buffer (50 mM Tris$\mathrm{HCl}, 2 \mathrm{mM}$ EDTA, $100 \mathrm{mM} \mathrm{NaCl}$ 100, $\mathrm{pH}$ 8,0). The resuspended cells were then re-centrifuged and 
the supernatant discarded as before. The wet cell pellet was then stored at $-20{ }^{\circ} \mathrm{C}$ until required. The non-induced and induced samples were analyzed by SDS-PAGE to check for effective protein expression.

Purification of inclusion bodies: A frozen cell pellet from $500 \mathrm{ml}$ of induced cell culture was resuspended in TES buffer containing $0.1 \%$ Triton X-100 and $100 \mu \mathrm{g} / \mathrm{ml}$ lysozyme and incubated at $30{ }^{\circ} \mathrm{C}$ for 30 min to lyse the cells. Bacterial DNA was degraded by DNase I at $20 \mu \mathrm{g} / \mathrm{ml}$ and $\mathrm{MgCl}_{2}$ at $7 \mathrm{mM}$ and incubation at room temperature until the solution was no longer viscous. The lysate was then centrifuged $\left(16,000 \mathrm{x} \mathrm{g}, 20 \mathrm{~min}, 4^{\circ} \mathrm{C}\right)$ after which the supernatant was decanted. The pellet containing inclusion bodies (insoluble fraction) was washed twice with TES buffer containing 1\% Triton X-100. During each washing step, the inclusion bodies were recovered by centrifugation as described above. Samples from all soluble and insoluble fractions were taken for analysis by SDS-PAGE.

Purification of $\mathbf{r C o n B r}$ by affinity chromatography on $\mathbf{~ N i}^{2+}$-chelating Sepharose column: The purified inclusion bodies prepared as described before were solubilized in binding buffer (Tris- $\mathrm{HCl} \mathrm{pH} \mathrm{7.5,500} \mathrm{mM} \mathrm{NaCl,} 5$ $\mathrm{mM}$ imidazole) containing $6 \mathrm{M}$ guanidine hydrochloride for $12 \mathrm{~h}$ at $4{ }^{\circ} \mathrm{C}$. After centrifugation $(16,000 \mathrm{x} \mathrm{g}, 20 \mathrm{~min}$, $4{ }^{\circ} \mathrm{C}$ ), the supernatant was applied to a chelating Sepharose fast flow column (Amersham Pharmacia Biotech, Sweden) previously charged with $\mathrm{Ni}^{2+}$ ions and then equilibrated with binding buffer containing $6 \mathrm{M}$ guanidine hydrochloride. After washing out the unbound material in binding buffer, contaminants that remained bound to the column were eluted with washing buffer (Tris- $\mathrm{HCl} \mathrm{pH}$ 7.5, $500 \mathrm{mM} \mathrm{NaCl}, 50 \mathrm{mM}$ imidazole) containing $6 \mathrm{M}$ guanidine hydrochloride. The recombinant lectin (rConBr) was then eluted with $500 \mathrm{mM}$ imidazole in the binding buffer. The fractions were pooled, dialyzed against distilled water, freeze-dried and stored at room temperature until used.

Electrophoresis, blotting and N-terminal sequencing analyses: SDS-polyacrylamide gel electrophoresis (SDSPAGE) was done as described by Laemmli [17]. Gels were blotted onto plyvinylidene (PVDF) membranes for $4 \mathrm{~h}$ at $1 \mathrm{~mA} / \mathrm{cm}^{2}$ and blots were stained with Ponceau S Red. Protein bands were excised, de-stained with water, and submitted to N-terminal sequence analysis on an Applied Biosystems Procise instrument following the manufacturer's instructions.

Western blot: Cellular and chromatographic fractions were checked for the presence of recombinant lectin by SDSPAGE [17] and Western blotting on nitrocellulose membranes (Life-Technologies, USA) using rabbit anti-ConBr IgG and goat anti-rabbit IgG conjugated to horseradish peroxidase (Calbiochem, USA). Antibody preparation (from rabbit antiserum produced against $\mathrm{ConBr}$ ) and Western blotting procedures followed standard methods [18].

\section{RESULTS AND DISCUSSION}

Expression of recombinant ConBr in $E$. coli was carried out by transforming the host strain BL21( $\lambda$ DE3) with the expression vector pET15b-conbr, which encodes the N-terminal, 30-amino acid signal sequence plus 
the 290-amino acid sequence of the precursor seed lectin (pre-pro-ConBr) [15-16]. In this vector, the recombinant protein is produced with a histidine tag sequence, which is a consecutive stretch of 6 histidine residues expressed at the amino terminus of the target protein. The histidine tag allows the expressed protein to be purified in one step by immobilized metal ion affinity chromatography (IMAC).

To check for effective recombinant protein production, samples of cell cultures were taken before and after induction of the heterologous gene expression by IPTG. The expression of $\mathrm{rConBr}$ in E. coli was analyzed by SDSPAGE and Western blot as shown in Fig. 1. The total cell protein content was run from both un-induced (no IPTG added) and induced cultures (with 1mM IPTG). It is evident in Fig. 1A that upon induction (lane 3), a large quantity of a protein with an apparent molecular mass of $37 \mathrm{kDa}$ is produced, which does not appear to be present in un-induced cultures (Fig. 1A, lane 2). All of this $37 \mathrm{kDa}$ protein was completely present in the insoluble fraction (Fig. 1A, lane 5), and there was no major band at the same position in the soluble fraction (Fig. 1A, lane 4). The $37 \mathrm{kDa}$ protein band present in insoluble fraction was completely recovered in the purified inclusion bodies (Fig. 1A, lanes 7 and 9). The two washing steps used in the protein bodies purification procedure were effective in removing some protein contaminants present in the insoluble fraction (Fig. 1A, lanes 6 and 8), leaving behind all the induced, $37 \mathrm{kDa}$ protein band in the inclusion bodies. Additionally, the $37 \mathrm{kDa}$ protein band present in the induced E. coli cell extracts and recovered as an insoluble fraction in the inclusion bodies was specifically recognized by rabbit polyclonal antibodies against the native lectin $\mathrm{ConBr}$ in Western blot experiments (Fig. 1B, lanes 2,3, 5 and 7). Furthermore, the absence of any cross-reactive material to anti-ConBr antibodies in the soluble fractions obtained after washing the inclusion bodies of induced cells (Fig. 1B, lane 4) confirms that all $\mathrm{rConBr}$ expressed in $E$. coli was recovered very efficiently.

This migration of approximately $37 \mathrm{kDa}$ corresponds well with the value found for the precursor of Concanavalin A (ConA), a lectin homologous to $\mathrm{ConBr}$ isolated from the closely related species Canavalia ensiformis, when it was expressed in E. coli JM109 [19], when the $2 \mathrm{kDa}$ histidine tag leader present at the Nterminal of $\mathrm{rConBr}$ is taken into account. The $30 \mathrm{kDa}$ lectin subunit of native $\mathrm{ConBr}$ was always included in these experiments as a control (Fig. 1). It is evident from the Western blot data that no protein band with an apparent mass around $30 \mathrm{kDa}$ that cross-reacts with anti-ConBr antibody is present in induced $E$. coli cells harboring the gene coding pre-pro-ConBr (Fig. 1B). Therefore, the difference in electrophoretic mobility is readily attributable to the absence of proteolytic processing of $\mathrm{rConBr}$ expressed in E. coli BL21( $\lambda \mathrm{DE} 3)$. Similar results were obtained for ConA expressed in E. coli cells [19]. 
A

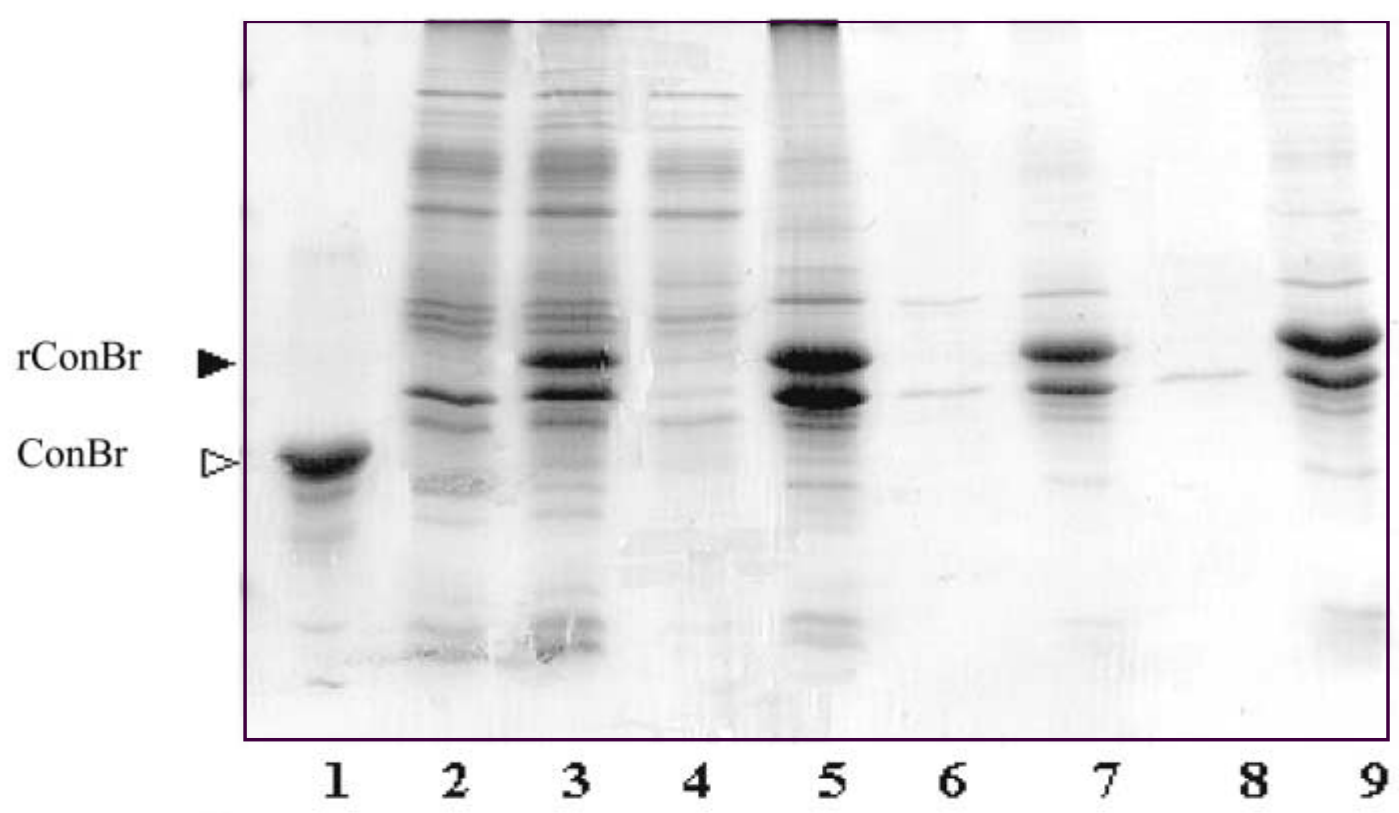

B

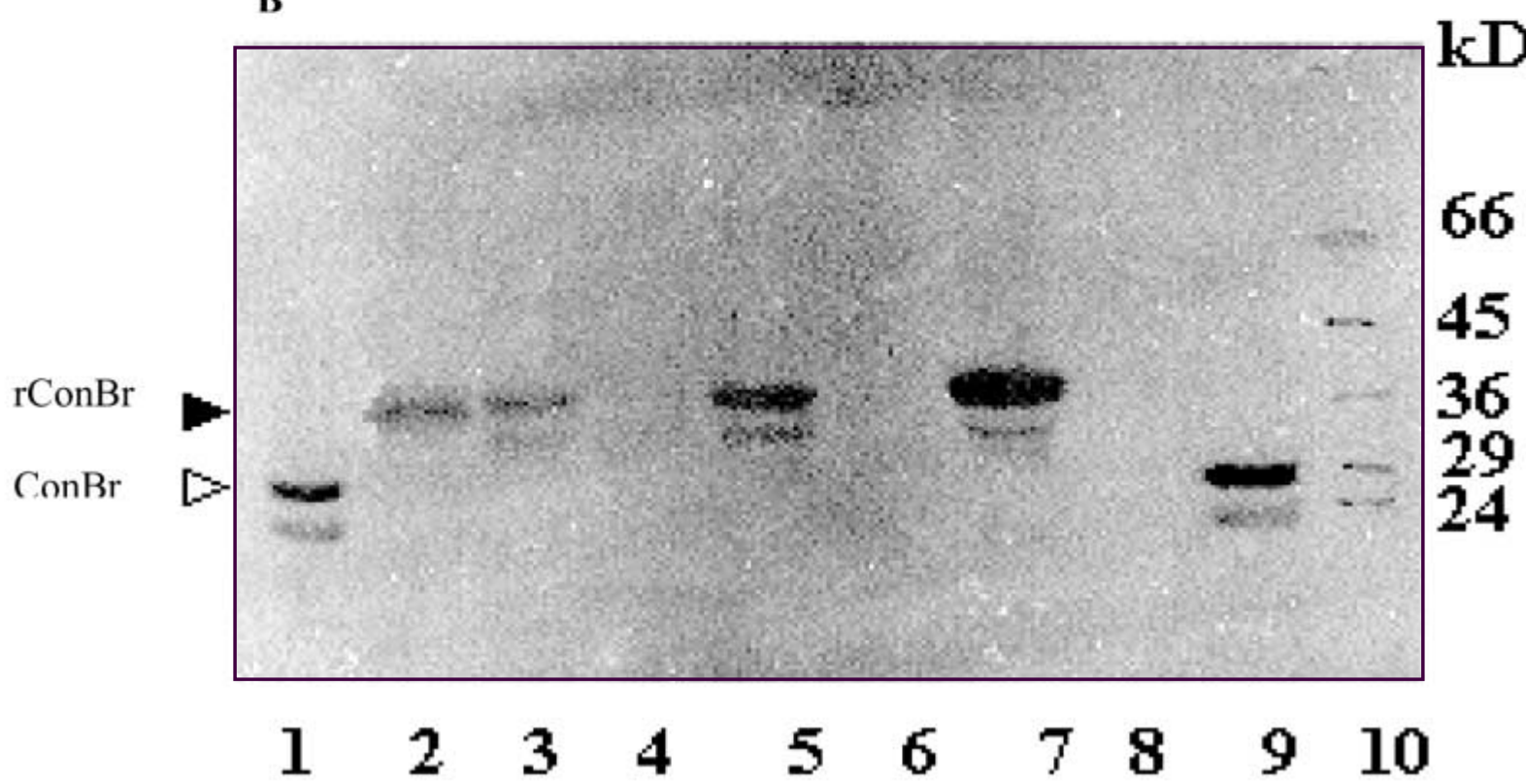

electrophoresis (SDS-PAGE) on a 12.5\% polyacrylamide gel and were either gel stained with Coomassie Brillant Blue (A) or submitted to Western blot analysis (B). The following samples were analysed: native ConBr (1A, 1B, 9B), crude extract of $E$. coli cells before the addition of IPTG (2A), crude extract of cells induced with $1 \mathrm{mM}$ IPTG for $5 \mathrm{~h}$ (3A, 2B), soluble $(4 \mathrm{~A}, 4 \mathrm{~B})$ and insoluble (5A, 3B) fractions of induced cells, supernatant fractions obtained after washing the inclusion bodies $(6 \mathrm{~A}, 8 \mathrm{~A}, 6 \mathrm{~B}, 8 \mathrm{~B})$, purified inclusion bodies (7A, 9A, 5B, 7B), molecular mass standards, from top to bottom: bovine serum albumin, egg albumin, glyceraldehyde-3-phosphate dehydrogenase, carbonic anhydrase and bovine trypsinogen (10B): The $37 \mathrm{kDa}$ protein band of $\mathrm{rConBr}$ as well as the $30 \mathrm{kDa}$ protein band of native ConBr are indicated by arrows.

The insoluble fraction of bacterial lysate of induced $E$. coli cells contained a high level of $\mathrm{rConBr}$ as seen on the SDS-PAGE (Fig. 1A, lanes 7 and 9), and these insoluble aggregates could be solubilized by treatment with $6 \mathrm{M}$ guanidine hydrochloride. The $\mathrm{rConBr}$ present in the solubilized inclusion bodies could be purified 
exploiting the presence of the 6 histidine tag on the $\mathrm{N}$-terminal end of the expressed protein. Therefore $\mathrm{rConBr}$ was purified to homogeneity under denaturing conditions by immobilized affinity chromatography using a $\mathrm{Ni}^{2+}$-chelating Sepharose matrix (Fig. 2). The protein fraction eluted from the $\mathrm{Ni}^{2+}$-charged gel with $500 \mathrm{mM}$ imidazole (peak III) showed a major $37 \mathrm{kDa}$ protein band when submitted to SDS-PAGE (Fig. 2, insert A) and this protein band present in peak III was specifically recognized by rabbit anti-ConBr IgG (Fig. 2, insert B). In addition, no cross-reactive material to anti-ConBr IgG was detected in peaks I and II (Fig. 2, insert B). These results show that binding of histidine-tagged $\mathrm{rConBr}$ to the chromatographic matrix was very efficient and the column was not saturated by the amount of protein applied to it.

This purification procedure will be very useful for the expression in E. coli of lectin mutants with alterations in residues that constitute the carbohydrate-binding site as well as in non-contact residues that may have long range effects on the thermodynamic parameters of the lectin's interaction with complex sugars. The average yield of purified rConBr expressed in E. coli was about $30 \mathrm{mg}$ of pure lectin per $\mathrm{ml}$ of culture medium. To our knowledge, this is the best yield of a plant lectin produced in E. coli so far [20].

$\mathrm{N}$-terminal sequence analysis of electroblotted samples of rConBr purified by immobilized metal-affinity chromatography revealed a single amino acid sequence: GSSHHHHHHSSGLVPRGSMAISKK. In this sequence, the six histidine tag is followed by a cleavage site (LVPRGS) for thrombin, both of which provided by the vector. The comparison of the sequence MAISKK with that deduced from the ConBr cDNA nucleotide sequence [15] confirms the identity of the expressed protein as the pre-pro-ConBr, and clearly shows that E. coli is unable to perform the complex posttranslational processing that pre-pro-ConBr undergoes in the plant cells during seed development [21]. Our results agree with those obtained earlier on the expression of pre-pro-ConA [19] and proConA [22] in E. coli JM109 cells. Although the rConBr expressed in E. coli did not undergo any posttranslational, proteolytic processing, as showed by the apparent molecular mass and the $\mathrm{N}$-terminal sequence of its subunit, the lectin had carbohydrate binding activity since it was readily retained when applied to a Sephadex G-75 matrix, which is a polymer of D-glucose (data not shown).

In vitro splicing and re-ligation of concanavalin $\mathrm{A}$ (and most probably of $\mathrm{ConBr}$ too) have shown to be catalyzed by an asparaginyl endopeptidase [23]. The reason for the occurrence of this extraordinary post-translational event during ConA (ConBr) maturation remains enigmatic because non-glycosylated pro-ConA and the two-chains form display both carbohydrate-binding activity. Based on the crystal structure of mature ConA, the splice site appears to be located on a surface loop, but crystallographic data of the pre-pro-lectin are not yet available. Our expression system may allow us to produce enough pre-pro-ConBr lectin for structural studies to establish whether splicing and religation are linked to major conformational rearrangement of the lectin monomer. 


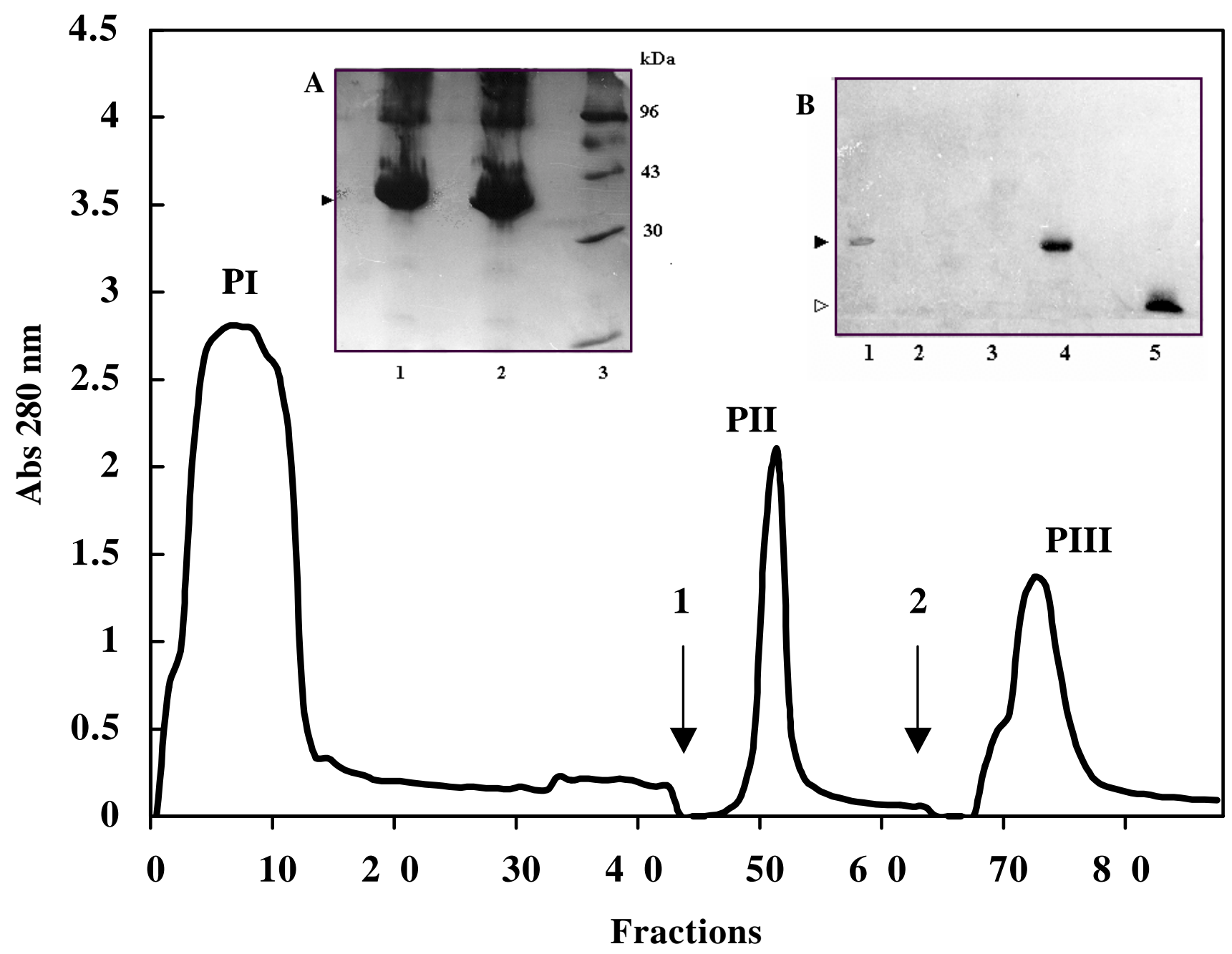

Fig. 2. Purification of recombinant $\mathrm{ConBr}$ by immobilised metal-ion affinity chromatography (IMAC) on a $\mathrm{Ni}^{2+}$-chelating sepharose fast flow column. Purified inclusion bodies of IPTG induce E. coli cells harboring pET15b-conbr were solubilised in binding buffer $(20 \mathrm{mM}$ Tris- $\mathrm{HCl} \mathrm{pH} 7.5,0.5 \mathrm{M} \mathrm{NaCl}, 5 \mathrm{mM}$ imidazole, $6 \mathrm{M}$ guanidine hydrochloride) and applied to the column equilibrated and first eluted with binding buffer. After eluting unbound material (peak I), protein contaminants (peak II) were eluted (1) from the gel in washing buffer (binding buffer $+50 \mathrm{mM}$ imidazole). The recombinant lectin (peak III) was recovered by washing (2) the column with eluting buffer (binding buffer $+500 \mathrm{mM}$ imidazole). Insert A: SDS-PAGE of $\operatorname{IMAC}$ purified $\operatorname{rConBr}(1,2)$; molecular mass standards (3). Insert B: Immunodetection of rConBr in chromatographic fractions. Crude extract of E. coli induced cells (1), Peak I (2), Peak II (3), Peak III (4) and native $\mathrm{ConBr}(5)$ were probed with rabbit anti-ConBr IgG. The $37 \mathrm{kDa}$ protein band of $\mathrm{rConBr}$ as well as the $30 \mathrm{kDa}$ protein band of native ConBr subunits are indicated by arrows.

\section{ACKNOWLEDGMENTS}

This work was supported by grants from Conselho Nacional de Desenvolvimento Científico e Tecnológico (CNPq), Fundação Coordenação de Aperfeiçoamento de Pessoal de Nível Superior (CAPES), Programa de Apoio ao Desenvolvimento Científico e Tecnológico (PADCT), and Fundação Cearense de Amparo a Pesquisa (FUNCAP).

T.B. Grangeiro, M. Barral-Netto and B.S. Cavada are senior investigators from CNPq. 


\section{REFERENCES}

[1] Van Damme, E.J.M., Peumans, W.J., Barre, A. and Rougé, P. (1998) Crit. Rev. Plant Sci., 17, 575-692.

[2] Summer, J.B. and Howell, S.F. (1936) American Journal of Bacteriology, 32, 227-237.

[3] Cunningham, B.A., Wang, J.L., Waxdal, M.J. and Edelman, G.M. (1975) J. Biol. Chem., 250, 1503-1512.

[4] Wang, J.L., Cunningham, B.A., Waxdal, M.J. and Edelman, G.M. (1975) J. Biol. Chem., 250, 1490-1502.

[5] Hardman, K.D. and Ainsworth, C.F. (1972) Biochemistry, 11, 1120-1128.

[6] Becker, J.W., Reeke, G.N., Wang, J.L., Cunningham, B.A. and Edelman, G.M. (1975) J. Biol. Chem., 250, 1513-1524.

[7] Moreira, R.A. and Cavada, B.S. (1984) Biologia Plantarum (Praha), 26, 113-120.

[8] Dam, T.K., Cavada, B.S., Grangeiro, T.B., Santos, C.F., Sousa, F.A.M., Oscarson, S. and Brewer, C.F. (1998) J. Biol. Chem., 273, 12082-12088.

[9] Dam, T.K., Cavada, B.S., Grangeiro, T.B., Santos, C.F., Ceccatto, V.M., Sousa, F.A.M., Oscarson, S. and Brewer, C.F. (2000) J. Biol. Chem., 275, 16119-16126.

[10] Gomes, J.C., Rossi, R.R., Cavada, B.S., Moreira, R.A., and Oliveira, J.T.A. (1994) Agents Actions, 41, $132-135$.

[11] Barral-Netto, M., Santos, S.B., Barral, A., Moreira, L.I.M., Santos, C.F., Moreira, R.A., Oliveira, J.T.A., and Cavada, B.S. (1992) Immunol. Invest., 21, 297-303.

[12] Rodrigues, D., Cavada, B.S., Oliveira, J.T.A., Moreira, R.A. and Russo, M. (1992) Braz. J. Med. Biol. Res., 25, 823-6.

[13] Bento, C.A., Cavada, B.S., Oliveira, J.T., Moreira, R.A. and Barja-Fidalgo, C. (1993) Agents Actions, 38, 48-54.

[14] Sanz-Aparicio, J., Hermoso, J., Grangeiro, T.B., Calvete, J.J. and Cavada, B.S. (1997) FEBS Lett., 405, $114-118$.

[15] Grangeiro, T.B., Schriefer, A., Calvete, J.J., Raida, M., Urbanke, C., Barral-Netto, M. and Cavada, B.S. (1997) Eur. J. Biochem., 248, 43-8.

[16] Grangeiro, T.B. (1996). PhD Thesis. 133 p. Universidade Federal do Ceará, Fortaleza.

[17] Laemmli, U.K. (1970). Nature, 227, 680-685.

[18] Sambrook, J., Fritsch, E.F., and Maniatis, T. (1989). Molecular Cloning: A Laboratory Manual. Cold Spring Harbor Laboratory, Cold Spring Harbor, NY.

[19] Min, W. and Jones, D.H. (1992) FEBS Lett., 301, 315-318.

[20] Nogueira, N.A.P. (1999). PhD Thesis. Universidade Federal do Ceará, Fortaleza.

[21] Cavada, B.S., Moreira, R.A., Oliveira, J.T.A. and Grangeiro, T.B. (1993). Rev. Bras. Fisiol. Vegetal, 5, $193-201$.

[22] Min, W., Dunn, A.J., and Jones, D.H. (1992). EMBO J., 11, 1303-1307.

[23] Min, W. and Jones, D.H. (1994). Struct. Biol., 1, 502-504. 